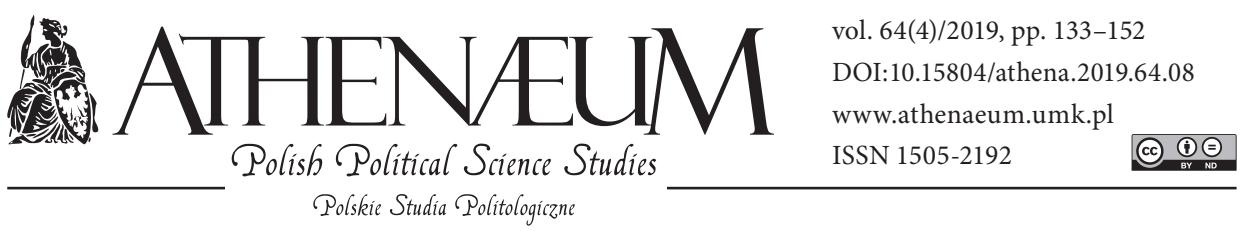

\title{
EAST EUROPEAN RESEARCH AS POLITICAL SCIENCE IN THE SECOND POLISH REPUBLIC
}

\author{
BADANIA WSCHODNIOEUROPEJSKIE JAKO DZIEDZINA NAUK \\ POLITYCZNYCH W II RZECZYPOSPOLITEJ
}

Ralph Schattkowsky* ๑)

\begin{abstract}
After the times of partitions and reunification of partitioned territories, organisation of science in the Second Polish Republic had become a political task, to which the scientists of all disciplines devoted themselves with great engagement. Historical studies had a special position in this process. They served finding the identity of society and the legitimacy of the modern Polish national state. On this basis not only close connection between science and politics were formed, but also personal links with often unclear boundaries between scientists and politicians. Considering the historical burden on relations to eastern neighbours, especially to Russia, research on Eastern Europe had a special responsibility. It provided the political argumentation for the Eastern European paradigms of Poland, as a location on the border of the Western civilisation, serving as a protection wall against Russian danger which proved to be especially dangerous in the form of Bolshevism for the whole area of Europe. In this field the traditional research on Russia cooperated equally close with politics and formed new fields
\end{abstract}

Po okresie rozbiorów i ponownego zjednoczenia podzielonych terytoriów organizacja nauki w II Rzeczypospolitej stała się zadaniem politycznym, któremu naukowcy wszystkich dyscyplin poświęcili się z wielkim zaangażowaniem. Studia historyczne zajmowały w tym procesie szczególną pozycję. Służyły odnalezieniu tożsamości społeczeństwa i legitymizacji współczesnego polskiego państwa narodowego. Na tej podstawie powstały nie tylko ścisłe powiązania między nauką a polityką, ale także osobiste powiązania z często niejasną granicą między naukowcami a politykami. Biorąc pod uwagę historyczne obciążenie relacji ze wschodnimi sąsiadami, zwłaszcza z Rosją, na badaniach nad Europą Wschodnią spoczywała szczególna odpowiedzialność. Stanowiły one polityczną argumentację dla wschodnioeuropejskich modeli Polski jako miejsca granicznego cywilizacji zachodniej, służącego jako mur ochronny przed zagrożeniem rosyjskim, które pod postacią bolszewizmu okazało się szczególnie groźne dla obszaru całej Europy. W tej dziedzinie tradycyjne badania nad Rosją pozostawały w ścisłej współ-

* Nicolaus Copernicus University in Toruń, Faculty of Political Science and Security Studies. 
of research, like formed in Poland Sovietology. In this constellation Poland decisively determined the level of research in Europe.

Keywords: history of science; Sovietology; East European history; Russian studies; Polish historical research pracy ze sferą polityki i tworzyły nowe dziedziny badań, jak ukształtowana w Polsce sowietologia. W takim układzie Polska zdecydowanie określiła poziom badań w Europie.

Słowa kluczowe: historia nauki; sowietologia; historia Europy Wschodniej; rusycystyka; polskie badania historyczne

The Eastern European dimension of the Polish state is a constitutive element of developing its power politics. Its identity-constructing role is not only essential during the state setup in the primary sense but also a decisive factor in the modern nation-building process. The certainty of belonging to the West European-Latin cultural sphere results in an exceptional geopolitical situation, which, given historical experiences, requires a specific degree of legitimacy. Under these conditions, both politics and society are facing the extraordinary challenge of permanently clarifying and assuring this position in response to situational dynamics. This is why science and research (and historical research in particular) play a key role in this area.

Since the beginning of the existence of the idea of a modern Polish state, ideas of lebensraum in the East have always been related to the expansion of the Russian empire. Without taking this into consideration, any effort to establish a culturalgeographical demarcation of Eastern-Central Europe remains incomprehensible and abstract. It is this division of Eastern Europe into the Polish-Lithuaniandominated historical space and Russia, perceived as the actual Eastern Europe that resonates in Polish ideas of statehood restoration - notwithstanding the fact that this concept remains contradictory in the context of nation-state building and cannot separate power-political and cultural-geographical dimensions from each other. Exactly this is reflected in the approach of Polish Eastern Europe research. It also highlights the importance of dealing with one's own East. Its potency and structural significance in the Polish understanding of the state were defined a priori through Russia's imperial ambitions. Research in the field of Polish state-building plans based on the common distinction between a Jagiellonian federative and a Piastic unitary project time and again underestimates or completely omits the diverse nuances, interpretations, and overlaps in and between the camps. However, they determine the East as the key to positioning Poland as an occidental European country. 
The emergence of an Eastern European research with an interdisciplinary character, its functionality in politics and its position in the scientific system is inseparable from Prometheism as both a model of action and an option of a Polish Eastern policy in the Second Republic. It provides a useful tool to identify institutions and individuals who published in scientific journals focused on the European East and took on a leading role in the effective propagation of an image of the Eastern Europe. In this political environment, beyond the elementary turning points of 1918,1926 and 1935, a milieu developed that represents a close connection between political public, scientific expertise and political engagement, placed the East in the history of the modern polish state and described it as an extremely flexible concept of thought. This is accompanied by the development of a peculiar type of researcher closely connected to and practicing politics, and of politicians as scientists who provide deep insight into the process of how politics influences research and how effectively science is involved in politics. As has been amply demonstrated for other European countries, the Polish case also shows that in the context of the configuration of a territorial state, close cooperation and synthesis of scientific justification and political reasoning are associated with a political determination of research, a sense of political entitlement of science, networking and personal contacts.

\section{ASSIGNMENT AS A SELF-COMMITMENT}

The Polish national movement was well prepared for the situation of a possible restoration of statehood in the First World War. After the uprising period, the politics of organic work created its own, modern social structures, which created good conditions for the establishment of a state. The concessions of the partition powers during the war concerning the restoration of a Polish state confirmed, despite all the questionability, at least a general awareness in Europe to resolve the Polish question, which put the Polish state project in a fairly comfortable position. On this basis, the Polish elites developed enormous activities to legitimize the state and territory. Apart from the fact that the modern nation has a great need for legitimacy, the determining political circles were strongly aware that Poland's reunion after partitions and different development processes that had taken place in the territories controlled by Russia, the Habsburgs, and Prussia required special identity-building justifications and rituals. A sound declaration of territorial claims was also necessary $v i s-\grave{a}$-vis the victorious powers, which had 
to formally determine the shape of the future Polish state. Above all, however, it was the geographical position between neighbours traditionally hostile to Polish statehood that explains this strong need for legitimacy and that generated particularly close relationship between science and politics. History and geography became those appellate bodies (Schweiger, 2014, p. 7) that had to prove the state and territory to be almost natural and undeniable. These historical-geopolitical approaches reflect the imperative of security policy connected with the founding of the Second Polish Republic.

Very much in the tradition of the partitions era in which the sciences, in the sense of organic work, were an essential part of the cohesion of the Polish people in the partition territories and an integral factor in the organization of society (Buszko, 1983, pp. 132-145; Bieńkowski, 1983, pp. 157-177; Juzwenko \& Wrzesiński, 1979, pp. 125-146), the sciences were assigned a central function in the construction and design of the Polish state. There was no doubt about their defining social role. However, discussions in the newly formed bodies arose as to how it should be performed without restricting the freedom of science. Historians in particular developed a strong sense of responsibility towards statehood and society. This was initially expressed in relation to the question of the eastern border, but, at the same time, it was already very generally articulated as a mediator of national values and in the service of national education (Suleja \& Wrzesiński, 1990, p. 156; Grabski, 2000, p. 166). In the very lively methodological discussion among Polish historians during the First World War, the Kraków legal historian Stanisław Kutrzeba had already pointed out the role of history in shaping everyday life and its influence on politics (Kolbuszewska, 2005, p. 173; Serejski, 1963, p. 612). The platform for a broad debate on the role of science in the construction of the new Poland was provided by the journal Nauka Polska. The journal was published as a yearbook by the Mianowski Support Fund for Scientists, which had already been instrumental in the preservation and formation of a nationally oriented Polish science during the partition period and practically figured as a "Ministry of Polish Sciences". The yearbook set out to report on the requirements, organization and tasks of the sciences, taking into account the social and psychological aspects as well as questions of scientific organization and effectiveness abroad' (Hartmann, 1962, p. 20). Well-known historians took this opportunity to express their views on the role of histori-

Nauka Polska: jej potrzeby, organizacja i rozwój: rocznik Kasy Pomocy dla Osób Pracujących na Polu Naukowym imienia Doktora Józefa Mianowskiego. I-XXIV (1918-1939). 
ography and the state of its development. The focus was on the relationship between the historical sciences and state and society, and the objective of the emancipation of the historical sciences from the partition-related regionalization and the external influence by the emerging state. It is particularly noteworthy that these reflections were always linked to a methodical and thematic orientation that considered both the international state of the art and the unique position of the Polish national sciences.

Already in the first volume of 1918, Jerzy Kochanowski devoted broad space to the relationship between "Polish thought" as Polish subjectivism and the objective approach to historical phenomena as a method of a general synthesis of history (Kochanowski, 1918, pp. 225-236). Although he does not question objective synthesis as the basic principle of historical research, he makes a purely practical case for a "Polish synthesis" of history. He justifies this above all with the traditional and defining foreign interpretation of both Polish and general history through the partition powers (in particular, German historical studies) and through the geographic and historical conditions of the existence of the Polish nation, which (through its cultural competence per se) gains an interpretative power, at least in its historical and power-political development space. Thus, he also sees in the study of the general history of Slavdom as one focus of Polish historical research and defines this field of research as a task in order to break the prevailing German and also Russian monopoly, and take it out of the "hands of foreigners" (Kochanowski, 1918, p. 229) who had developed a fundamentally unfriendly and hostile perspective on history. Nor should one ever turn a blind eye to the fact that Poland is permanently threatened by these neighbours. At the same time, however, Kochanowski is no less concerned with the application of sound research standards of analysis and comparison that would enable Polish scientists, through "Europeanising the level of Polish sciences" (Kochanowski, 1918, p. 231), to stand in front of the "high altar of civilization" (Kochanowski, 1918 , p. 226) equally entitled as the representatives of other countries. For Kochanowski the immediate task is to concentrate on Polish history in the Slavic context through the development of the sources and the historical and geographical determination and legitimization of the Polish state (Kochanowski, 1918, p. 235).

An explanation of both of these issues through the history of the Polish people, and thus from a sociological-ethnological perspective, is a central demand of the contribution of Jerzy Smoleński in the same volume (Smoleński, 1918 , pp. 237-242). In doing so, he not only ties in with the internationally 
established approaches to popular research but also directly serves the aspect of cultural impact. Polish history in particular can not only be explained by individual aspects of its political and economic history or the development of society, but history as a science must open up to the full spectrum of the life of the population. As a consequence, Smoleński's contribution is a plea for a cultural history, or a history "from below", by seeing only the possibility of collecting the cultural achievements of the Polish people in order to consistently analyse Polish history. These achievements could then serve as evidence of their individuality and creative abilities. He refers to international research and calls for greater consideration of ethnology for Polish historical research. The quintessence of his reflections is the establishment of the uniformity and individuality of the Polish people from a regionally determined ethnic diversity, from which the medieval Polish state developed. The Rzeczpospolita, on the other hand, evolved from a state of many peoples who did not assimilate and retained their individuality in a "common territory of state-parliamentary life" (Smoleński, 1918, p. 242). The Polish cultural superiority alone ensured the permanent expansion of civilization in the eastern territory in the Western European spirit. This civilizational element was also the decisive factor for Smoleński for a moral unification, which for him stood above a merely state-based unity and was able to secure the cohesion of the Rzeczpospolita beyond the loss of state independence.

A year later, Tymieniecki's contribution (also in Nauka Polska) initially completes the inventory of historical sciences (Tymieniecki, 1919, pp. 148-172). Very much like his colleagues, he confirms the great potential of Polish historical research and sees good conditions for the organization of a potent historical science in the Polish state. Without renouncing the reference to the international standard, however, he is even more focused on concentrating on Polish history with his own powers. The foreign influence, especially the German one, on the interpretation of Polish history must be eliminated once and for all, and the reflection on one's own must take absolute precedence. For example, all publications should only be published in Polish and there should be no publications in other European languages (Tymieniecki, 1919, p. 166). The author sees the greatest challenge in overcoming the contradiction between scientific theory and life-worldly practice, which in his view is particularly pronounced in Poland. This "iron door" between the world of scientists and practical life must be pushed open (Tymieniecki, 1919, p. 151). He puts the social function of the sciences at the heart of his argument and demands that the sciences should get closer to life: "The people have the right to demand of the historians that the views 
of historians on their own history are accessible and understandable to all" (Tymieniecki, 1919, p. 152). He sees this not only as a central task but also an important expression of regained state sovereignty through the possible practice of self-interpretation. The practical consequence is then not only an independent analytical preparation of one's own history but also a methodically demanding scientific journalism in a generally understandable form, which would overwhelm the historian. Although he continues to perceive historical science and journalism as two separate and independent forms that cannot replace each other, he does indeed concede a dissolution of the clear boundaries in the context of the specific requirements and the consideration of historical experience. This view proved to be very decisive for the dissemination of historical knowledge in the Second Republic not only on the journalistic level but it also affected the relationship between research and politics in general.

These basic trends of stocktaking and initial reflections on a strategy of the Polish sciences were confirmed and extended at the First Polish Congress of Science in Warsaw in April 1920 (Nauka Polska,3). Under the theme of "Science and State", Tymieniecki formulated as a central thesis that the sciences have to serve society and, above all, the state, and that a scientific programme for legitimizing the borders of the Polish state should be developed. At the congress, the committee of the Mianowski Fund called for the development of "close-to-life sciences" and defined the social and historical sciences as the central instances for imparting scientific knowledge to the wider society (Suchodolski, 1992, p. 85; Jaczewski, 1978, p. 95). The renowned social and economic historian from Lwów, Franciszek Bujak (Shelton, 1989, p. 56; Krzoska, 1994, p. 431), designated himself as the spokesperson and subordinated historiography to the nation-state task and saw the historian's task as the protection of their own nation from the interests of others. According to Bujak, this national task consisted primarily of a special attentiveness of research towards the East and the Slavic people (Bujak, 1920, pp. 64-74). Another renowned historian, Władysław Semkowicz, saw the way to realize these tasks in the necessary overcoming of any particularism and the planned scientific organization through the cooperation and unification of forces, for any "individualism must lead to anarchy in the field of scientific work" (Semkowicz, 1920, pp. 109-118).

When the Secretary General of Polska Akademia Umiejętności, the forerunner of the Polish Academy of Sciences, Stanisław Kutrzeba, considers it the main task of science to serve the state (Kutrzeba, 1920, pp. 83-97), this is certainly not to be regarded as a servile cliché. It rather expresses the close connection 
between society and the state. This view was also evident in almost all other talks referring to "society". People, nation, society and the state are thought of in close symbiosis, if not used interchangeably. Although these proposals were also met with scepticism, they highlighted the widespread logic of a state commitment and the widespread obligation towards the new state as a task. The Congress and the discussion in the Nauka Polska did not leave the slightest doubt about this. In parallel with this human science perspective, the technical sciences emphasized the need for close links with the economy but not, however, without insisting on the autonomy of the sciences (Jaczewski, 1987, p. 222). The natural scientists in general resisted such functionalization. This led to a permanent conflict in which the Warsaw historian Marceli Handelsman took an important position for social scientists, stressing the purposefulness and social significance of research while insisting on preserving the individual freedom of the researcher (Handelsman, 1925, p. 3). This issue led to repeated conflicts between science and the state, as the Second Congress in 1927 shows, but the argument of service to the state ultimately prevailed. This was certainly also linked to the construction of science funding, which was primarily administered within the discretion of the ministry. The criticism was not primarily directed against state governance and influence but rather against a lack of interest on the part of the state authorities in science and the notorious under-funding (Jaczewski, 1987, p. 223).

The analyses and recommendations of these very influential historians are certainly programmatic in nature (Grabski, 2000, p. 166). It would be exaggerated, however, to conclude that the development of Polish historical studies of the interwar period was aligned accordingly. The external conditions were too unstable, and the impact of political dynamics on the financing of science too big. It seems certain, however, that the formulated basic positions represented guidelines providing strong orientation for both historical sciences and political journalism. This refers above all to the civilizational role of Poland from the cultural and geopolitical point of view and the positioning of a Polish statehood in the European West-East dualism, which granted Poland a high degree of independence associated with a genuine leading role. At the same time, it is also the orientation towards a broad scope of the historical sciences and, as it were, their opening up to both political exploitation and social functionality, combined with the task of the publication of historical insights by social elites (Kolbuszewska, 2005, p. 172). Moreover, science was concerned with international impact from the outset, which is certainly related to the young Polish state's claim to visible positioning in the context of other states, but is also due to the strong networking 
of scientists, who had gained high reputation during partition time abroad and brought it into the scientific structure.

\section{STATE IMPULSE AND “POLITICAL THINKING"}

From 1919, the Ministry of Religious Affairs and Public Education (Ministerstwo Wyznań Religijnych i Oświecenia Publicznego - MWRiOP) formally took over the management of the Polish scientific establishment and founded its own science department for this purpose (Jaczewski, 1987, p. 206). However, the relationship between state and science remained relatively disordered and, together with the ongoing economic difficulties of the state, caused some displeasure. Above all, it was about planning security and overcoming permanent under-funding, which was in strong contrast to the state's demands and the development of society. It was precisely this problem and, above all, the danger of falling further behind internationally that was the starting point of an initiative of scientists organized by the journal Nauka Polska in 1928 (Vol. 10). Well-known scientists from all fields lamented the current situation in which the sciences could no longer keep up with the real and necessary development of society and thus addressed the very point that was always emphasized by state and politics. They strongly criticized the relevant ministries and called for a decidedly better endowment of the scientific institutions and a visible increase in the number of staff. From the human sciences, sociologists spoke out particularly clearly, underscoring the practical socio-political importance of sociology for the modern Polish state. The scientists also formed organizational structures and were able to exert massive pressure on the state authorities, not least because they acted unanimously. Against the background of a significantly improving economic situation in the country, the ministry reacted quite quickly to the demands, in turn stressing the importance of science and the close connection to the state. The Sanacja [Sanation] fully laid claim to economic progress and thus also legitimized the marked increase in its influence in all spheres of politics and society. In the same year, visible measures were taken to meet the demands. One can speak of a visible improvement in the situation, which also benefited the human sciences. In particular, the history and culture of the Slavic peoples should be promoted. At the same time, however, the continuing structural weakness of scientific life in eastern Poland was also pointed out, Wilno and Lwów, of course, holding a special position. 
The state's grip on the sciences was particularly evident in its influence on structural and personnel decisions. Walery Sławek, a close confidant of Piłsudski, renewed the principle that science should serve the state, formulated after the founding of the state, and now connected it directly with Piłsudski's intentions, which served as a yardstick. In his role as organizer of the Nonpartisan Bloc for Cooperation with the Government (BBWR), which acted openly antidemocratically and considered it his main task to directly influence politics according to Piłsudski's vision, Sławek also tried to attract scientists. Given the dissatisfaction with the scientific policies of the governments, he was fairly successful. The Sanacja also benefited from the dislike of the type of nationalism proposed by the National Democracy, which was fairly widespread among the intelligentsia. This made the Piłsudski's camp an acceptable alternative, especially since it was oriented towards and closely connected to the person of Piłsudski but politically quite heterogeneous. Thus, it was neither possible to form a solid front of the intelligentsia behind Piłsudski nor to force it into line as in dictatorships. However, the political commitment of academics and their role in state and parliamentary bodies was not insignificant. A representative example of active work in the government camp is the professor of canonical law at Wilno University and its later vice-chancellor Professor Stefan Ehrenkreutz, initiator and president of the Scientific Research Institute for Eastern Europe in Wilno (Kornat, 2000, pp. 3-119).

1928 was undoubtedly a pivotal year in the negotiation of the relations between the state and the sciences. One key result was the creation of the National Cultural Fund which, although it offered a good opportunity to improve the financial resources of scientific institutions, also enabled public authorities to have a major influence on the management of funds. Due to the visibly improved financial resources, numerous institutes were newly established and international scientific cooperation intensified. However, it was only a short-lived upswing. In the autumn of 1929, Poland was also considerably affected by the Great Depression and funding for science was cut drastically and for a longer period. The pre-crisis level was not reached again until 1937. Political strife increased dramatically at the beginning of the 1930s, and scientists positioned themselves more strongly. Stefan Ehrenkreutz, for example, led the Group for Culture and Education of the Ministry of Education and, together with other influential professors, took an important position in this crucial but ultimately anti-democratic instrument. The conflict between science and state continued to escalate, and protests increased with the result that the relevant state agencies 
responded with increased pressure on oppositional professors, the liquidation of some chairs and the obstruction of disloyal professors. Halecki and Handelsman, for example, were denied stays abroad.

\section{SCIENTIFIC QUESTIONS AND "GEOPOLITICAL IMPERATIVE"}

The greatest challenge of the new Polish state was to bring together the three parts of Poland that had existed before reunification. This was primarily a structural problem of socioeconomic unification. But it was no less the task of a spiritualintellectual self-determination and the search for a unification of thought. Not in the sense of levelling, but as a strategy of thought that seems appropriate for a modern Polish nation-state. This is certainly not a specifically Polish problem and concerns cum grano salis all modern nation states, or all modern nationalization processes. Determining what belongs to one and separating it from the foreign is the core problem. However, this process, despite its comparability, had a specific dimension in Poland under the conditions of the partitions. Not least because the partition of the traditional Polish state territory, and thus also the various forms of the segregation of society, took place in a period that was generally crucial for the design of modern societies and the development of modern nation states, including a completely new system of relationships. Economics, technology, science and thought developed rapidly, and participation in this development was in no small measure decisive for the possibilities of powerpolitical development and positioning in the international system. In Poland, for example, the foreign influence on the sciences, especially the social sciences, was perceived as a curse and a blessing in equal measure. The top intellectuals had enjoyed their education in the metropolises of the partitioning powers. The universities in St. Petersburg, Berlin and Vienna were centres of thought and home to the most innovative minds of their time. Polish intellectuals, especially historians, thus contributed state-of-the-art social science research to the new Polish state. At the same time, the self-image of this state was strongly influenced by an emancipation from this external influence, which required the intellectual elites to distance themselves clearly from the partition powers in every respect. Since a denial of the intellectual contributions did not seem to make much sense and because they were also needed as intellectual tools for the construction of the new state, this distancing manifested itself above all in the attempt to bind all intellectuals to state and nation through "Polish thinking" as a methodical 
leitmotif and a focus on national history, the depiction of which should no longer be left to Germans and Russians. What mattered was not only to dominate this field of research but also, in the sense of establishing "Polish thinking", to address actively the formulated points of view of the neighbours. This included an intense and permanent observation of their activities in this field.

It is no wonder, therefore, that research fields that dealt with the neighbours were established quite quickly. The geopolitical paradigm foregrounded Germany and Russia. The national historical aspect dominated here, too. This means that there was less concern with the history of or the knowledge about the neighbour than with its role in the development of the Polish state and its influence on its social design. The task of this research was also practically oriented from the outset and had to serve the development of the new Polish state. Research took on tasks that went far beyond the field of "pure" historical research, connected itself closely with politics and also aligned itself with the different directions of "political thought". At first, most of the attention was devoted to the western neighbour. It was not only thought to pose the greatest potential threat for the young Polish state, but this focus was also in line with the nation-state model realized by the founding of the state in 1918, which was favoured by the Polish national democracy and considered Piastic Poland as the systemic and territorial model. The task of such Western research then also consisted in the legitimization of the territorial changes in the German-Polish border area and the closely related examination of German influence on Polish history and, above all, any form of the Kulturträgertheorie. In the 1920s, a number of organizations and institutes were created, devoted exclusively to this task: the Society of the West Territories' History Enthusiasts (Towarzystwo Miłośników Historii Ziem Zachodnich) - 1922, the Baltic Institute in Toruń (Instytut Bałtycki) - 1925, the Silesian Institute in Katowice (Instytut Śląski) - 1934, and the Committee for the Study of the History of Silesia (Komitet Badania Historii Śląska) - 1928. In addition, there were a number of journals that assigned themselves to these fields of research. The newly founded University in Poznan was also committed to Western research. The first general congress of Polish historians after the war took place in Poznan and dealt with Western Slavdom and its assertion against the German influences in the western Polish territories (Serejski, 1963, p. 22). Increasingly, the confrontation with the Drang nach Osten ('urge to the East') has moved into the focus of research assuming an almost natural German aggressiveness. This Western research then found its almost classical expression 
in the founding of the West Institute in Poznan and the person of Zygmunt Wojciechowski, and is well-reflected in the research literature.

Historians and geographers saw it as their most noble task not only to scientifically substantiate the claim, even the necessity, of the incorporation of the Kresy into the new Polish state, to prove their reasoning with the history of the Polish-Lithuanian Empire and to support it with geopolitical imperatives. But they were also involved in the decisive political camps and acted as experts in determining committees. With Oskar Halecki and Eugeniusz Romer, leading authorities in their field whose international reputation was beyond doubt, were mustered. Their virulent preoccupation with the East was also due to the experience they had gained in Galicia as an intellectual and political centre of partitioned Poland. In the Habsburg-governed part of Poland, the quasi-autonomy provided structural conditions to engage intensively with the restoration of the Polish state. This was the centre of the national movement with the universities of Kraków and Lwów providing the intellectual site of the scientific foundation of the future territorial form (Maternicki, 1990, pp. 11-45; Wandycz, 1992, p. 1015).

As the heartland of the Kresy, however, the eastern dimension of the Polish state was also lived and experienced here, and the exploring of the relationship with Russia as well as the attitude to the Ukrainian question were central aspects of everyday politics. Zygmunt Wojciechowski, who used his concept of "mother countries" (a country that is "responsible" for another, usually smaller country) to propagate Western thought in the sense of a Polish western border along the river Oder and the Baltic Sea and who became the father of Western Research, stems from this intellectual milieu (Krzoska, 2003, p. 43).

Romer studied in Lwów and began his scientific career there. In 1910, he was appointed as chair of the Institute of Geography. From research stays with Albrecht Penck in Vienna, he took his first suggestions for a Volks- and Kulturboden perspective on geography. Romer was heavily involved in the patriotic movement and saw his main field of activity in promoting Poland's future borders (Zierhoffer, 1967, p. 328).

He characterised his main work, the Geographical-Statistical Atlas of Poland (Romer, 1916), to be charged with the "dynamics of Polish statehood" (Romer, 1988, p. 103). He later also played an important role in the border determinations at the Paris Peace Conference. Heavily influenced by Friedrich Ratzel and German Länderkunde (country studies, i.e., regional geography), he assumed a geographical determinism of statehood (Romer, 1939; Wapiński, 1989, pp. 66, $92,157,227,337)$ and understood the Polish state as a natural geographical entity 
essentially within the borders of 1772 (Romer, 1916, p. 19). This meant that any changes to this construction contradicted the nature of Polish statehood, and were thus unnatural and endangering its existence. Poland as a "land between the seas" was an integral part of Romer's Western Europe as its easternmost part. Thus the location and justification of Poland's eastern border took on a special significance in his argument concerning the shape of the new Polish state. Russia is the East. All ethnic factors only played a subordinated role in this approach or were completely disregarded. The physical geography of the state alone was the ordering element, and all possible national factors would be "amalgamated" by the attractiveness of Polish culture (Romer, 1918, p. 359). So when Romer spoke of an "urge to the East", he did not associate a civilizational mission but a natural expansion task of Poland as a Western European project with a permanent character. Romer derived the conviction that geography could serve as a firm appellate body of Polish territorial form and state legitimacy from the purely objective and neutral character of geography as an unadulterated science, which in the struggle for the Polish independence must be put at the service of the state.

Many of these ways of thinking by Romer and his geography can also be found in Halecki's historical argument. Specialized in Jagiellonian Poland, he saw this model as the future for a Polish state. He was a member of the Polish National Committee and, as an expert of the Polish delegation, campaigned at the Paris Peace Conference for "historical rights" of the Polish state in Galicia and Volhynia (Bömelburg, 2007, p. 107).

The advocacy of a state federation of Poland with Lithuania and the Ukraine as a major European power brought him into the closest connection with Piłsudski's political camp at an early stage. While, in contrast to Romer, he acknowledged distinctive national interests of Lithuanians and Ukrainians, he saw it not as an essential problem in view of the decentralized organization of the state but as an "internal question of the common state" (Halecki, 1918, p. 1). In doing so, he left no doubt about the clear Polish character of the state and, similarly, saw Romer's cultural dominance of Polishness as a self-regulating element. Far more than Romer's, Halecki's historical perspective was strongly characterised by the conviction of a key position of the eastern territories of the Polish state. On the other hand, however, he was also very close to Romer, deriving this fixation from a special bond between region/nature and the population, as a source of life of Polish statehood. With the ideal type of the Polish-Lithuanian Union as a model and orientation towards the borders of 1772, Halecki connected a historic mission of the Poles in the East (Halecki, 1920, p. 8). It consisted, above all, in the 
ability to pacify this transitional area between Poland and the East, which in itself appears unstable; and only a Polish state that exists there as a leading power can exercise an antemural function and balance the opposition of East and West. This function includes a permanent battle with Russia seeking dominance in Eastern Central Europe, and it will mobilize all the internal forces of the state, thereby, for Halecki, assigning both an internal and external function to this historical constellation of Polish statehood.

Like Romer, Halecki was convinced of a national task of science and argued for history to put itself at the service of politics. For him, an active participation in the political process of creating and consolidating the new Polish state was beyond question. The conviction that shaping the relations with the East played a special role was underlined by his active participation in Polish Eastern politics in the early 1920s. When analysing the writings of such exposed researchers as Romer and Halecki, it is difficult to maintain the view that they were exclusively committed to science. The political purposefulness of their research did not allow for any kind of "neutrality". It was a self-formulated task to serve the state project and to set out basic patterns of thought with regard to the position to the European East, which, well beyond the normal reach of scientific historicalgeographical research, influenced social perspectives and political attitudes (Zernack, 1991, p. 72).

Similarities in Romer and Halecki's view on the role and meaning of the East are unmistakable. What Romer claimed to be the natural geographical physiognomy of the Polish state was historically charged by Halecki with the PolishLithuanian ideal. The result was a geopolitical imperative of Polish statehood, which decisively shaped the Eastern European research in the Second Polish Republic and formed not insignificantly the spiritual roots for what was later called Prometheism. From the outset, the subject of this research included not only historical, geographical, and political considerations, but there was always self-determination, even self-assurance - not only in the territorial dimension of the state but also in finding an identity. A comparison with Eastern Europe supported the self-image of Poland as European. Poland as an integral part of the Latin West or the Occident was not only proof of cultural quality but also provided the legitimacy of a function in the East which combined a European protection function and a cultural mission (Wierzbicki, 1993, p. 272).

Eastern European research developed a special understanding of space of a dispositive character $v i s-\grave{a}$-vis the Kresy. The Kresy were seen as a transitional space or inter-space, endangered by imperial claims of Russia and entitled to 
Poland. Poland fulfilled a traditionally orderly function (pacification) in this area, thus securing its own existence and a Latin Western cultural mission as the only force capable, through its culturally Western character, to protect European values from danger from the East and to take on this European obligation. The position towards this space follows from a permanent confrontation with Russia as the actual Eastern Europe presenting a major threat potential. Due to this bipolar Eastern European perspective, it is difficult to speak of uniform Eastern Europe research at the beginning of the $1920^{\mathrm{s}}$ because different perspectives were developed and a uniform research approach did not exist. Eastern European research existed in the dualism of one's own and the foreign, and developed an internal and an external perspective.

It was only later, towards the end of the 1920s, but above all dominant in the 1930s, that research aimed at Russia and its eastern neighbours developed complementary to Western research. This focus is certainly related to the seizure of power by Piłsudski in May 1926 and (again) a stronger orientation towards the East. In 1927, initiated by Poland and under the direction of Marceli Handelsman, the first congress of historians from Eastern Europe took place in Warsaw, and in 1930, Eastern European Institutes were founded in Warsaw and Wilno, as well as a number of journals devoted exclusively to questions of Eastern Europe. The University of Wilno played a key role in Eastern European research, and Lwów and Kraków were also assigned such a research focus - but without living up to that as expected. With the stronger turn to the East, the preoccupation with the "Jagiellonian idea" as a model of Polish state constitution became popular once again, placing the eastern expansion of the Polish state and the ideal image of a community of different peoples in the focus of historical considerations. Just as the Piastic example for the West, the Jagiellonian model did not only serve to legitimize the existing state constitution but also served more ambitious goals of a concept of big-power politics, and similarities between this power-political habitus and the "urge to the East" were quite present (Serejski, 1963, p. 24).

The focus of research on the Piastic and Jagiellonian ideas went far beyond the dichotomy of regional research priorities and dominated all historical research. Here, in a way, the processes of modernization of the Polish social sciences (Kolbuszewska, 2005, p. 172; Niederhauser, 1988, p. 110) were consolidated and, simultaneously, the traditional schools of the optimistic and pessimistic view of Polish history dissolved (Maternicki, 1961, p. 335). Without achieving formal party-political conformity, the basic political positions of the National Democracy and the Piłsudski's camp found expression and historical legitimacy, 
and perspective here. Strongly taken with the defined task of social functionality, historical consideration not only underwent a pronounced politicization but was also required to assign itself to political purposes and to consider respective guidelines. Moreover, it broadened forms and levels of representation, which opened up personal access with a high acceptance of opinions that could not be necessarily assigned to the academic camp. This did not mean that scientific journalism should not meet research standards, but the boundaries between influential opinion-forming and source-based studies were not necessarily questioned. Methodically, this phenomenon is further consolidated by the fact that the practical claim or direct exploitability, and the social benefits of research require less a chronological or historical treatise but are rather object-oriented. And only then, against the background of historical argumentation, research serves legitimatory purposes. This does not have to lead to a shallow argument with a merely propagandistic character, on the contrary, arguments are usually fiercely debated and profoundly supported with historical facts, which in turn requires expertise with a research background. And this is where historians, publicists and politicians meet in a wide variety of publications. This means that despite all the political inspiration, the publications cannot be denied a scientific character because their authors often have a scientific background and claim to work scientifically. Thus, scientific reasoning, object determination and description become a means of addressing current social tasks under certain political conditions.

This dissolution of the border between journalism and science, and the establishment of a close connection, if not mutual dependency, is one of the most important results of the abandonment of positivism and the modernization of the historical sciences at the turn of the century. It is an integral element of the greater focus on the more recent history of Poland and its embedding in European history, especially in the geopolitical context of the central location between East and West. The intensive reflections on the Europeaness of Poland and the efforts to prove to belong to the Western-Latin cultural sphere in the interwar period can only be understood in this context, too. The modernization of Polish historical research and its practice in the Second Republic also means the definitive departure from the idea of historical research as a science committed only to objectivity. Instead, it receives a certain place in state and society where historians have to share their social function with others in the field of historical journalism and to compete to dominate (public) opinion - not only on the basis of the differentiation of one's own subject but also with authors whose journalism 
has been fully granted a research background or a professional competence. In the end, their social classification, acceptance and effectiveness will ultimately become decisive. The social pressure was correspondingly high. The crucial factors in the development of research were precisely the expectations of politics and society. These increasingly teleological expectations were unambiguously geared towards clear answers to the current needs of the time and affected by the political narrowing in the Second Polish Republic. All of this narrowed the scope of historical research, hampered method discussions and ultimately the creative development of research. Historical research could particularly flourish in fields where the degree of correspondence between the requirements of research and political demands or special interests was particularly high - and that was the Eastern European research in the 1930s.

\section{REFERENCES:}

Bieńkowski, W. (1983). Die polnischen wissenschaftlichen Institutionen zwischen der Revolution von 1905 und dem Ersten Weltkrieg. In: R.G. Plaschka, \& K. Mack (eds.). Wegenetz europäischen Geistes. Wissenschaftszentren und geistige Wechselbeziehungen zwischen Mittel- und Südosteuropa vom Ende des 18. Jahrhunderts bis zum Ersten Weltkrieg (pp. 157-177). Wien: Verlag für Geschichte und Politik.

Bömelburg, H.J. (2007). Zwischen imperialer Geschichte und Ostmitteleuropa als Geschichtsregion: Oskar Halecki und die polnische "jagiellonische Idee". In: F. Hadler, \& M. Mesenhöller (eds.). Vergangene Größe und Ohnmacht in Ostmitteleuropa. Repräsentationen imperialer Erfahrung in der Historiographie seit 1918 (pp. 99-130). Leipzig 2007: AVA.

Bujak, F. (1920). Nauka a społeczeństwo. Nauka Polska, 3, 64-74.

Buszko, J. (1983). Organisatorische und geistig-politische Umwandlungen der Universitäten auf polnischem Boden in der zweiten Hälfte des 19. Jahrhunderts. In: R.G. Plaschka, \& K. Mack (eds.). Wegenetz europäischen Geistes. Wissenschaftszentren und geistige Wechselbeziehungen zwischen Mittel- und Südosteuropa vom Ende des 18. Jahrhunderts bis zum Ersten Weltkrieg (pp. 132-145). Wien: Verlag für Geschichte und Politik.

Grabski, F.A. (2000). Zarys historii historiografii polskiej. Poznań: Wydawnictwo Poznańskie.

Halecki, O. (1918). Polens Ostgrenze im Lichte der Geschichte Ostgaliziens, des Chelmer Landes und Podlachiens. Wien: M. Perles.

Halecki, O. (1920). Granica z roku 1772 a nasz program obecny (2). Wschód Polski, 4, 1-11.

Handelsman, M. (1925). Nauka - funkcja społeczna. Nowiny, 3. 
Hartmann, K.H. (1962). Hochschulwesen und Wissenschaft in Polen. Entwicklung, Organisation und Stand 1918-1960. Frankfurt/M-Berlin: Alfred Metzner Verlag. Jaczewski, B. (1978). Polityka Naukowa Państwa Polskiego w latach 1918-1939. Wrocław: Ossolineum.

Jaczewski, B. (1987). Życie naukowe w Polsce odrodzonej. In: B. Jaczewski (ed.). Życie naukowe $w$ Polsce $w$ drugiej połowie XIX $i$ w XX wieku. Organizacje i instytucje (pp. 206-210). Wrocław: Ossolineum.

Juzwenko, A., \& Wrzesiński, W. (1979). Modernisierung und Neugestaltung des polnischen nationalen Lebens im russischen und preußischen Teilungsgebiet im 19. und zu Beginn des 20. Jahrhunderts. In: W. Conze, G. Schramm, \& K. Zernack (eds.). Modernisierung und nationale Gesellschaft im ausgehenden 18. und im 19. Jahrhundert: Referate einer deutsch-polnischen Historikerkonferenz Wirtschaftsforschung des europäischen Ostens (pp. 125-146). Berlin: In Kommission bei Duncker \& Humblot.

Kochanowski, J.M. (1918). O potrzebach nauki polskiej w zakresie historii. Nauka Polska, 1, 225-236.

Kolbuszewska, J. (2005). Mutacja modernistyczna w historiografii polskiej (przełom XIX i XX wieku). Łódź: Ibidem.

Kornat, M. (2000). Początki sowietologii w II Rzeczypospolitej. Geneza, dzieje i dorobek Instytutu Naukowo-Badawczego Europy Wschodniej w Wilnie (1930-1939). Zeszyty Historyczne, 134, 3-119.

Krzoska, M. (1994). Die polnische Geschichtswissenschaft in der Zwischenkriegszeit. Ein Überblick. Zeitschrift für Geschichtswissenschaft, 42(5), 430-436.

Krzoska, M. (2003). Für ein Polen an Oder und Ostsee. Zygmunt Wojciechowski (1900-1955) als Historiker und Publizist. Osnabrück: Fibre Verlag.

Kutrzeba, S. (1920). Nauka a państwo. Nauka Polska, 3, 83-97.

Maternicki, J. (1961). Historia polityczna czy historia integralna? Dyskusja nad zagadnieniem przedmiotu syntezy dziejów narodowych w dziejopisarstwie polskim lat 1914-1939. Zeszyty Historyczne, 2, 330-376.

Maternicki, J. (1990). Geografia historiograficzna II Rzeczypospolitej. Przeglad Humanistyczny, 34(2), 11-45.

Niederhauser, E. (1988). Szkoły historyczne a polityka w europie wschodniej do 1945. Kwartalnik Historyczny, 95(4), 105-134.

Romer, E. (1916). Geograficzno-statystyczny atlas Polski. Warszawa-Kraków: Gebethner i Wolff.

Romer, E. (1918). Die Nationalitäten in Chelm und Podlachien. Polen. Wochenschrift für polnische Interessen, 169, 359-365.

Romer, E. (1939). Ziemia i państwo. Kilka zagadnień geopolitycznych. Lwów-Warszawa: Książnica-Atlas.

Romer, E. (1988). Pamiętniki. Problemy sumienia i wiary. Kraków: Znak.

Schweiger, A. (2014). Polens Zukunft liegt im Osten. Polnische Ostkonzepte der späten Teilungszeit (1890-1918). Marburg: Herder-Institut.

Semkowicz, W. (1920). Organizacja pracy naukowej. Nauka Polska, 3, 109-118. 
Serejski, M. (1963). Historycy o historii. Vol. 1. Od Adama Naruszewicza do Stanisława Kętrzyńskiego 1775-1918. Warszawa: PWN.

Shelton, A.K. (1989). The Democratic Idea in Polish History and Historiography: Franciszek Bujak (1875-1953). New York-Boulder: East European Monographs.

Smoleński, W. (1918). Potrzeby historii polskiej. Nauka Polska, 1, 237-242

Suchodolski, B. (ed.). (1992). Historia Nauki Polskiej, Vol. 5: 1918-1951. Wrocław: Ossolineum.

Suleja, W., \& Wrzesiński, W. (1990). Spory o narodową i społeczną funkcję historyków polskich. In: S.K. Kuczyński (ed.). Polskie Towarzystwa Historyczne 1886-1986. Zbiór studiów i materiałów (pp. 147-169). Wrocław: Ossolineum.

Tymieniecki, K. (1919). Uwagi o niektórych potrzebach historii w Polsce i o warunkach jej dalszego rozwoju. Nauka Polska, 2, 148-172.

Wandycz, P. (1992). Historiography of the Countries of Eastern Europe: Poland. American Historical Review, 97(4), 1011-1025.

Wapiński, R. (1989). Świadomość polityczna w Drugiej Rzeczypospolitej. Łódź: Wydawnictwo Łódzkie.

Wierzbicki, A. (1993). Spory o polska duszę. Z zagadnień charakterologii narodowej $w$ historiografii polskiej XIX $i$ XX $w$. Warszawa: IH PAN.

Zernack, K. (1991). Preußens Ende und die ostdeutsche Geschichte. In: K. Zernack, W. Fischer, \& M.G. Müller (eds.). Preußen - Deutschland - Polen. Aufsätze zur Geschichte der deutsch-polnischen Beziehungen (pp. 65-84). Berlin: Duncker und Humblot.

Zierhoffer, A. (1967). Eugeniusz Romer. In: B. Olszewicz (ed.). Dziewięć wieków geografii polskiej. Wybitni geografowie polscy (pp. 297-359). Warszawa: Wiedza Powszechna. 